Georgetown University Law Center

Scholarship @ GEORGETOWN LAW

2015

\title{
The Triumph of Gay Marriage and the Failure of Constitutional Law
}

Louis Michael Seidman

Georgetown University Law Center, seidman@law.georgetown.edu

This paper can be downloaded free of charge from:

https://scholarship.law.georgetown.edu/facpub/1499

http://ssrn.com/abstract=2636386

2015 Sup. Ct. Rev. 115-146

This open-access article is brought to you by the Georgetown Law Library. Posted with permission of the author. Follow this and additional works at: https://scholarship.law.georgetown.edu/facpub

Part of the Civil Rights and Discrimination Commons, Constitutional Law Commons, Judges Commons, Jurisprudence Commons, and the Legal History Commons 


\section{The Triumph of Gay Marriage and the Failure of Constitutional Law}

\section{Louis Michael Seidman*}

Writing in these pages more than four decades ago, Harry Kalven, Jr. referred to the Supreme Court's decision in New York Times v. Sullivan ${ }^{1}$ "an occasion for dancing in the streets." ${ }^{2}$ Contemporary news accounts fail to indicate that anyone actually took advantage of the occasion. In contrast, there was actual dancing, in the streets among many other places, when the Court announced its decision in Obergefell v. Hodges. ${ }^{3}$

The Court's much anticipated invalidation of gay marriage bans improved the personal lives of millions of ordinary Americans. It vindicated the courageous leaders who struggled for years on behalf of an unjustly despised, ridiculed, and persecuted minority. It made the country a more decent place. Even Chief Justice Roberts, at the conclusion of his otherwise scathing dissent, acknowledged that the decision was a cause for many Americans to celebrate. ${ }^{4}$

But although the Chief Justice thought that advocates of gay marriage should "by all means celebrate today's decision," he admonished them "not [to] celebrate the Constitution." The Constitution, he said, "had nothing to do with it." ${ }^{5}$

This article has three Parts. Part I quarrels with the Chief Justice's assertion that the Constitution "had nothing to do with it." I argue that it is the dissenting justices, rather than their colleagues in the majority, who have ignored the traditions of American constitutional law.

* Carmack Waterhouse Professor of Constitutional Law, Georgetown University Law Center. Thanks to Martin Lederman, Eric N. Lindblom, Allegra McLeod, Sherally Munshi, Mark Tushnet, and participants at the Georgetown Law Center Summer Workshop for comments on an earlier draft and to Richard Kelley for outstanding research assistance.

1376 U.S. 254 (1964).

2 Harry Kalven, Jr., The New York Times Case: A Note on the Central Meaning of the First Amendment, 1964

SUP CT. REV. 191, 221 n. 125 (quoting Alexander Meiklejohn).

$3 \quad 135$ S. Ct. 2584 (2015).

4 See id., at

$5 \quad$ Id. 
Part II argues that the Chief Justice is exactly right when he says that we should celebrate the Obergefell decision, but not the Constitution, but he is right for reasons that he, himself, would disagree with. The Court's decision marks a partial and flawed but nonetheless important advance toward inclusion and decency. The majority's opinion, replete with invocations of supposedly binding force of constitutional obligation, belittling of the large and growing number of Americans who are unmarried, and mischaracterization of the nature of the movement for gay rights, is exclusionary, reactionary, and authoritarian. Even as the Court demonstrates its (concededly limited) capacity to advance the cause of social justice, it unwittingly also demonstrates the failure of constitutional law to serve its core purpose of providing a just ground for cooperation among people who disagree about fundamentals.

A brief concluding Part discusses the implications of that failure.

I. "[N]othing to do with it"?

Contrary to the Chief Justice's assertion, and for better or worse, Obergefell fits comfortably within the constitutional law canon. The decision is no more audacious than Marbury v. Madison, ${ }^{6}$ no more inconsistent with original understanding than Brown v. Board of Education, ${ }^{7}$ no more contrary to tradition than Roe v. Wade, ${ }^{8}$ no more antimajoritarian than Miranda v. Arizona. ${ }^{9}$

True, the opinion lacks the analytic paraphernalia that too often clutters the Court's contemporary work. There is no discussion of tiers of review, suspect classes, strict scrutiny, or narrow tailoring. These matters were also left undiscussed in Marbury, Brown, Roe, and Miranda. Perhaps the Chief Justice thinks that these cases were also wrongly decided, but he cannot deny that they were decided in the way that they were. Unless he wishes to embark on the radical project of saving "the

5 U.S. (1 Cranch) 137 (1803).

347 U.S. 483 (1954).

410 U.S. 113 (1973).

384 U.S. 436 (1966). 
Constitution," understood in a purely abstract sense, from generations of constitutional tradition, his claim will not withstand analysis. Embarking on this project would require not only overruling Marbury, Brown, Roe, and Miranda, but also disavowing many of his own opinions on subjects like affirmative action and executive power, which are no more grounded in text, original understanding, tradition, and majority acquiescence. ${ }^{10}$

Thus, the claim that Obergefell marks a break with the tradition of American constitutionalism will not withstand analysis. One need not look far to find opinions that are in conflict with that tradition, however. In ways that are sometimes jarring but often subtle and obscured, the dissenters demonstrate their own disdain for well-understood strands of constitutional jurisprudence.

There is an inverse relationship between the vitriol and abuse dished out in these opinions and their analytic content. At one extreme - really in a class by itself -- is Justice Scalia's diatribe. The opinion is filled with the sort of personal abuse and invective that unfortunately has become his trademark. ${ }^{11}$ Even as measured by Justice Scalia's own standards, though, the opinion is extraordinary. In the entire history of the Supreme Court, there is nothing that rivals it for petulance, name calling, and disrespect.

10 See, e.g., Parents Involved in Community Schools v. Seattle School Dist. No. 1, 551 U.S.701 (2007) (Roberts, C. J.) (invalidating decision by political branches to utilize race to promote desegregation of schools despite absence of clear textual prohibition on the practice, evidence drawn from the original understanding of the text, or a well-established tradition prohibiting the practice); Free Enterprise Fund v. Public Company Accounting Oversight Board, 561 U.S. 477 (2010) (Roberts, C.J.) (inventing a new rule prohibiting political branches from establishing "double insulation" of removal of inferior office from the President despite the absence of textual support for the rule and no prior tradition establishing it).

${ }_{11}$ See, e.g., King v. Burwell, 135 S Ct. 2480, 2496, 2506 (2015) (Scalia, J., dissenting) (accusing the majority's opinion of being "quite absurd" and asserting "the discouraging truth that the Supreme Court of the United States favors some laws over others, and is prepared to do whatever it takes to uphold and assist its favorites"); Romer v. Evans, 517 U.S. 620, 653 (Scalia, J., dissenting) ("Today's opinion has no foundation in American constitutional law, and barely pretends to."); United States v. Windsor, 133 S.Ct. 2675, 2709 (2014) (Scalia, J., dissenting) (“I promise you this: The only thing that will 'confine' the Court's holding is its sense of what it can get away with.) 
According to Justice Scalia, the Court's decision amounts to a "judicial Putsch." ${ }^{12}$ It is "egotistic,"13 reflects "astound[ing] ... hubris," ${ }^{14}$ lacks "even a thin veneer of law,"15 is "profoundly incoherent,"16 and relies on "the mystical aphorisms of the fortune cookie." ${ }^{17}$ In place of actual argument against the majority's opinion, Justice Scalia makes observations about the religious affiliation of the Justices ("[n]ot a single Evangelical Christian ... or even a Protestant of any denomination") $)^{18}$ and criticizes Justice Kennedy's writing style (noting that he would "hide my head in a bag" if "even as the price to be paid for a fifth vote" he joined an opinion containing the Court's rhetoric. ${ }^{19}$ )

It is hard to know how one should treat this outburst. The sad fact is that Justice Scalia has become a caricature of his earlier self. He embarrasses even many of his ideological friends. Perhaps the discreet and humane thing to do is to ignore him. The problem is that it is not easy to ignore one of the nine people making constitutional policy for the country, and constitutional pundits rarely make the effort. Instead, people who should know better routinely praise Justice Scalia for his brilliance, integrity, and scintillating writing style. It therefore seems necessary to point out that in recent years he has made a habit of substituting vitriol for anything resembling reasoned analysis.

When they are on their best behavior, Supreme Court justices exhibit generosity of spirit, tolerance of disagreement, and respect for their intellectual opponents. It has been a long time since

\footnotetext{
12135 S. Ct. at __ (Scalia, J., dissenting).

13 Id. at

$14 \quad$ Id. at

15 Id. at

$16 \quad$ Id. at

17 Id. at

18 Id. at _. In fairness, the statement is made to demonstrate that the Court lacks diversity, and Justice Scalia makes clear that lack of diversity would not matter if the Court were merely interpreting the law; he claims that it is not Still, the argument makes sense only if he is asserting that the majority's decision is influenced by the religious beliefs of the justices- an extraordinary charge that is supported by no evidence. For whatever it is worth, two of the five justices in the majority have self-identified as Roman Catholics, and the Catholic Church has been a steadfast opponent of same-sex marriage.

$19 \quad$ Id. at
} 
Justice Scalia has been on his best behavior. Just as his ideological friends fear, and perhaps unfairly, he discredits the very causes that he wishes to advance.

Justice Thomas's dissent is more substantive and less vitriolic, but no less idiosyncratic. All of the dissenting opinions, including Justice Thomas's, are studded with odes to humility, caution, history, and tradition. ${ }^{20}$ Yet Thomas himself seems remarkably cavalier about our legal tradition. On his view, "it is hard to see how the 'liberty' protected by the [due process clause of the Constitution] could be interpreted to include anything broader than freedom from physical restraint." ${ }^{21}$ If adopted, this interpretation would lead to wholesale overruling of scores of cases extending over almost a century, on subjects ranging from incorporation of bill of rights protections against the states, ${ }^{22}$ to procedural due process cases, ${ }^{23}$ to decisions protecting against government prohibitions on contraception ${ }^{24}$, abortion, ${ }^{25}$ private schooling, ${ }^{26}$ and family living arrangements. ${ }^{27}$ Justice Thomas is nothing if not consistent. He seems to have a more-or-less worked out theory, applied over a wide range of cases, for why virtually all of modern constitutional law has gone off track. Still, one must ask: who is the real radical on the Supreme Court?

\footnotetext{
20 See, e.g., id. at _ (Roberts,C. J. dissenting); id. at __ (Scalia, J., dissenting); id. at __ (Thomas, J., dissenting); id. at __ (Alito, J., dissenting).

$21 \quad$ Id. at

22 See, e.g., Cantwell v. Connecticut, 330 U.S. 296 (1940) (holding that the free exercise clause was applicable to the states through the liberty protections of the fourteenth amendment's due process clause). 23 See, e.g., Perry v. Sindermann, 408 U.S. 593 (1972) (holding that interest in continued employment was part of liberty entitled to procedural protection under the fourteenth amendment's due process clause). $24 \quad$ See, e.g., Griswold v. Connecticut, 381 U.S. 479 (1965) (holding that right of married person to contraception is guaranteed against state infringement by liberty provision in due process clause of fourteenth amendment).

25 See, e.g., Roe v. Wade, 410 U.S. '113 (1973) (holding that abortion right is guaranteed against state infringement by liberty provision in due process clause of fourteenth amendment).

26 See Pierce v. Society of Sisters, 268 U.S. 510 (1925) (holding that state statute prohibiting private education violated liberty provision of fourteenth amendment).

27 See, e.g., Moore v. City of East Cleveland, 431 U.S.494 (1977) (holding that municipal ordinance restricting occupancy in any dwelling to members of the same, narrowly defined family violated liberty provision of fourteenth amendment).
} 
Perhaps it would make sense to dispose of all these decisions if Justice Thomas's rival theory were coherent and attractive. But it does not. Justice Thomas claims that this killing field for precedent is required by the original understanding of the fourteenth amendment. Even on the flawed assumption that unadulterated originalism is either an important part of our constitutional tradition or an attractive methodology, it is hard to reconcile it with Thomas's defense elsewhere in his opinion of natural law as a check on unjust positive law.

The tension is most apparent when Thomas turns to his criticism of the majority for relying upon human dignity. Citing the Declaration of Independence, Thomas complains that the majority undermines a key premise of the natural law tradition - that "dignity is innate and [does not come] from the Government." ${ }^{28}$ As Thomas puts the point:

Slaves did not lose their dignity . . . because the government allowed them to be enslaved. Those held in internment camps did not lose their dignity because the government confined them. And those denied governmental benefits certainly do not lose their dignity because the government denies them benefits. The government cannot bestow dignity, and it cannot take it away. $^{29}$

These jurisprudential musings are deeply confused. Of course, there is nothing confused about the claim that that human dignity and rights are prepolitical. That claim is at the center of an honorable and venerable natural law tradition that has played an important role in our constitutional history. But no one identified with that tradition, including presumably Justice Thomas, would claim that because government cannot deprive people of their intrinsic dignity, we should therefore defer to political decisions that are inconsistent with dignity.

If the government enforced slavery or established internment camps, would Justice Thomas really give it a free pass on the theory that these actions could not and did not take away human dignity? Perhaps he would if there were no constitutional text that governed the practice, but then one

$28 \quad$ Obergefell v. Hodges, 135 S. Ct. (2015) (Thomas, J., dissenting).

$29 \quad$ Id. at


must ask who is it whose theory is not attendant to human dignity? The more conventional understanding of the natural law tradition is that claims to dignity give courts a place to stand when they invalidate government decisions that are inconsistent with human dignity.

Precisely because the government cannot grant or take away human dignity - precisely because dignity is prepolitical - political institutions cannot redefine dignity to suit their purposes. On this view, courts can invalidate laws that are inconsistent with human dignity because positive law cannot take precedence over immutable concepts that must be respected if law is to be legitimate. And if courts should do this for slaves and internees, then why not for gay men and lesbians? Justice Thomas's invocation of natural law is therefore in tension with his own criticism of the majority for not deferring to positive law and the political process.

Justice Alito's worry about the "rights of conscience" ${ }^{30}$ of people who oppose same sex marriage suffers from a similar contradiction. His opinion, like those of the other dissenters, includes a criticism of the majority for "usurp[ing] the constitutional right of the people to decide whether to keep or alter the traditional understanding of marriage," ${ }^{31}$ and ignoring "[t]he system of federalism [that] provides a way for people with different beliefs to live together in a single nation." 32 I will have more to say about these claims later. ${ }^{33}$ For now, though, it is worth considering the tension between them and the argument, which he also advances, that the Court has ignored the "rights of conscience" of those who disagree with gay marriage. He claims that if the Court had not intervened, states might have tied recognition of same sex marriage to protection for "conscience rights" and that "[t]he majority today makes that impossible." 34

$\begin{array}{ll}30 & \text { Id. at } \_ \text {(Alito J., dissenting). } \\ 31 & \text { Id. at } \\ 32 & \text { Id. at } \\ 33 & \text { See pp xx-xx, infra. } \\ 34 & \text { Obergefell v. Hodges, } 135 \text { S. Ct. }\end{array}$
(2015) (Alito, J., dissenting). 
Perhaps Justice Alito means to confine this criticism to instances where government officials are required to enforce the Court's decision. If so, the complaint is at odds with the Supreme Court's longstanding insistence on its own primacy in constitutional interpretation. We do not generally recognize the "conscience rights" of officials to violate the Constitution as interpreted by the Supreme Court. Would Justice Alito excuse a police officer who, out of conscience, searched a suspect in violation of the Supreme Court's interpretation of the fourth amendment? Would he accommodate a school superintendent who conscientiously opposed racial desegregation ${ }^{35}$ or a department of motor vehicles employee who refused to provide licenses to women on the ground that the Koran, properly understood, prohibits women from driving?

It seems more likely that Alito is concerned about private individuals - the much discussed wedding caterer - who might be forced to participate in gay marriages. But if this is his concern, then his assertion that the majority makes protection for these people "impossible" is flatly wrong. Nothing in the Court's opinion requires states to provide gay couples with the legal right to force private individuals to participate in gay weddings. If individual states do decide to provide this right, nothing in the Court's opinion prevents them from tying the protection to exemptions for people conscientiously opposed to gay marriage. And if states do provide antidiscrimination protection and decline to provide conscience exemptions, then the fault - if, indeed, it is a fault - lies not with the Supreme Court but with the very democratic majority that Justice Alito elsewhere in his opinion claims should resolve matters related to gay marriage. Justice Alito leaves no doubt as to his personal judgment that same-sex marriage opponents should not be "labeled as bigots and treated as such by governments, employers,

35 Cf. James M. Oleske, Jr., The Evolution of Accommodation: Comparing the Unequal Treatment of Religious Objections to Interracial and Same-Sex Marriages, 50 HARV. C.R-C.L. L. REV. 99 (2015). 
and schools." ${ }^{36}$ Of course, he is entitled to that judgment, but if local majorities disagree with him, his own embrace of democratic federalism leaves him with no standing to object.

Invocations of majoritarianism, judicial restraint, and respect for different views also lie at the heart of Chief Justice Roberts' opinion, the most extensive and carefully reasoned of the four dissents. The opinion nonetheless overflows with ironies and contradictions. Perhaps the most disturbing is his analogy between the majority's decision and the Court's decision upholding slavery in Dred Scott v. Sandford. ${ }^{37}$ The comparison will strike many as morally obtuse. Put simply, requiring states to permit free individuals to choose gay marriage is nothing like allowing states to enslave African Americans. Indeed, among the many fundamental rights denied to slaves was the right to marry and form families. How can the Chief Justice invoke a decision that cruelly withheld the right to marry to criticize a decision that grants the right?

There is a second reason why the Chief Justice Roberts' Dred Scott analogy fails. Unlike the majority opinion in Obergefell, Chief Justice Taney's opinion in Dred Scott did not purport to rest on controversial claims about human flourishing. On the contrary, Taney insisted that it was "not the province of the court to decide upon the justice or injustice, the policy or impolicy of these laws. The decision of that question belonged to the political or law-making power." 38

In the most notorious passage in his opinion, Taney referred to African Americans as " beings of an inferior order, and altogether unfit to associate with the white race, either in social or political relations; and so far inferior, that they had no rights to which the white man was bound to respect." 39 But, importantly, Taney did not assert that these views were his own. On the contrary, he distanced

\footnotetext{
$36 \quad$ Id. at

3760 U.S.(18 How.) 393 (1857). Chief Justice Roberts discusses the comparison at Obergefell v. Hodges, 135 S. Ct. ___ (2015)

38 Dred Scott v. Sandford, 60 U.S. (18 How.) 393, 403 (1857).

$39 \quad$ Id. at 407.
} 
himself from them. These were the views that others held "more than a century before." 40 According to Taney, "[i]t is difficult at this day to realize the state of public opinion in relation to that unfortunate race, which prevailed in the civilized and enlightened portions of the world at the time of the Declaration of Independence, and when the Constitution of the United States was framed and adopted." 41

For Taney, racist views about African Americans were relevant not because they were correct (although, at least in slightly diluted form, he thought that they were), but because they helped interpret the original understanding of constitutional text. Taney purported to do precisely what Chief Justice Roberts chastises the Obergefell majority for failing to do. At least on his own account, Taney scrupulously abstained from injecting his own moral and political judgments into the decisional calculus and modestly deferred to judgments made by the Framers.

Modern historians continue to argue about whether Taney's interpretation of the text was correct, ${ }^{42}$ but that argument is not at the heart of why Dred Scott is so reviled today. The opinion is part of our constitutional anti-canon not because Taney departed from original text and understanding, but because his insistence on adhering to his reading of the text led him to ignore the huge moral issue at stake. Of course, slavery is a greater evil than the failure to recognize gay marriage, but if the analogy between Dred Scott and Obergefell is useful at all, it undermines rather than supports Chief Justice Roberts' point.

\footnotetext{
$40 \quad$ Id.

$41 \quad$ Id.

42 Compare DONALD E. FEHRENBACHER, THE DRED SCOTT CASE: ITS SIGNIFICANCE IN AMERICAN POLITICS AND LAW XX(1978) (arguing that Taney misinterpreted the Constitution) [check] with MARK A GRABER, DRED SCOTT AND THE PROBLEM OF CONSTITUTIONAL EVIL 12 (2006) (arguing that "slavery unambiguously pervaded the antebellum constitutional order.")
} 
Roberts' invocation of the other famous decision in the anti-canon - Lochner v. New York ${ }^{43}-$ better serves his argument. Lochner might more plausibly be interpreted as an example of the Court's confusion of its own stunted moral and political judgments for those embodied in constitutional text. Just as use of the word "liberty" in the Fourteenth Amendment did not "enact Mr. Herbert Spencer's Social Statics," ${ }^{44}$ so too, it might be thought, use of the word did not enact the views of The Human Rights Campaign.

But although the Lochner analogy is more on point, it, too has problems. One problem is that it is no longer so clear that Lochner is part of the anti-canon. A growing number of conservatives are prepared to embrace Lochner as embodying important constitutional principles. ${ }^{45}$ Moreover, in an odd way, some of Lochner's opponents agree with these conservatives. They, too, think that the Court could not escape taking a stand on issues of economic justice. The problem, in their view, was not that Lochner adopted a contestable set of political and economic assumptions, but that it adopted the wrong political and economic assumptions. ${ }^{46}$ If one holds this view, Obergefell is easily distinguishable because it adopts the right assumptions.

Of course, both the embrace and critique of Lochner on substantive grounds runs into the difficulty that people disagree about which assumptions are right and wrong. How can constitutional law retain the respect of "people of fundamentally differing views" ${ }^{47}$ if the correctness of a decision rests on the merits of those views? I return to this problem in Parts II and III of this article. For now, it is enough to see that Chief Justice Roberts' rival "judicial activism" critique of Lochner misconceives both the problem and the solution.

\footnotetext{
$43 \quad 198$ U.S. 45 (1905).

$44 \quad$ Id. at 65 (Holmes, J., dissenting).

45 See, e.g., DAVID E. BERNSTEIN, REHABILITATING LOCHNER (2011); RANDY E. B ARNETT, RESTORING THE LOST CONSTITUTION: THE PRESUMPTION OF LIBERTY 260-69 (2004). See generally Thomas B. Colby \& Peter Smith, The Return of Lochner, 100 CORN. L. REV. 527 (2015).

$46 \quad$ See, e.g., Cass Sunstein, Lochner's Legacy, 87 COLUM. L. REV. 873 (1987).

$47 \quad$ Lochner v. New York, 198 U.S. 45, 76 (1905) (Holmes, J., dissenting).
} 
The critique misperceives the problem because it assumes that Lochner and Obergefell impose a contestable judgment on people who disagree. For Justice Holmes, dissenting in Lochner the Court "decided [the case] upon an economic theory which a large part of the country does not entertain." 48 Similarly, for Chief Justice Roberts and the other Obergefell dissenters, the Court "closed the debate and enacted their own vision of marriage as a matter of constitutional law." 49

The first problem with this criticism, at least as applied to Obergefell, is that it misrepresents the obstacle to a political resolution of the marriage problem. In fact, it is Chief Justice Roberts and his dissenting colleagues who are out of step with a large and growing majority that favors gay marriage. ${ }^{50}$ The main obstacle to political resolution is state constitutional measures that prohibit gay marriage. If Chief Justice Roberts and his colleagues had their way, in many states, gay marriage would have to gain supermajority support in order to overturn these constitutional provisions much as supermajority support would be necessary to overturn Obergefell. To use Chief Justice Roberts' own words, state constitutions "close[] debate and enact[] their own vision of marriage as a matter of constitutional law" $^{\prime 1}$ There is a sense, then, in which it is the Court and not the dissenters who stand for majority rule.

But there is a more fundamental problem with Chief Justice Roberts' criticism. It is simply not true that, as the Chief Justice claimed, the Supreme Court "enacted [its] own vision of marriage as a matter of constitutional law" any more than it is true that the Lochner Court mandated long working hours. Ironically, these criticism would be more powerful if the laws invalidated in Lochner and Obergefell had been upheld. New York imposed mandatory maximum hour restriction on all New York

$48 \quad$ Id. aty 65 (Holmes, J., dissenting).

49 Obergefell v. Hodges, 135 S. Ct. 2584, ___ (2015) (Roberts, C.J., dissenting).

50 For example, according to a Washington Post/ABC News Poll taken within two months of Obergefell, sixtyone percent of Americans favored gay marriage while thirty-five percent were opposed. See Scott Clement \& Robert Barnes, Poll: Gay-Marriage Support at Record High, Wash. Post, ap. 23, 2015, available at http://www.washingtonpost.com/politics/courts_law/poll-gay-marriage-support-at-recordhigh/2015/04/22/f6548332-e92a-11e4-aae1-d642717d8afa_story.html.

51 Obergefell v. Hodes, 135 S. Ct. 2584, __ (2015) (Roberts, C.J., dissenting). 
bakery owners and bakery workers because of the controversial view that working more than ten hours per day was harmful and wrong. Similarly, the states that outlawed state-sanctioned gay marriage adopted a particular view of marriage that was not universally shared and imposed it on everyone. It was not the Lochner and Obergefell majorities that were forcing everyone to adhere to a uniform view. The decisions forced no one to work for more than ten hours or to marry a partner of the same sex. Instead, it left the decision to individuals.

Viewed in this way, it becomes clear that Chief Justice Roberts' criticism of Lochner and Obergefell not only has things backward; it also rests on a non sequitur. The argument starts with the accurate premise that people disagree with about maximum hours legislation and gay marriage, but then jumps to the fallacious conclusion that therefore the disagreement should be settled for everyone by majoritarian institutions. To see that the conclusion does not follow from the premise, we need only transfer the argument to a different sphere. No one says that because people disagree about the nature of God, therefore, the United States should use democratic processes to adopt a uniform religion for everyone. On the contrary, in at least this setting, disagreement about religion leads to the conclusion that people should be free to decide for themselves what they think about God.

The real dispute, then, is not between courts on the one hand and political institutions on the other, but between public decisions that bind everyone and private decisions that permit individual choice. People who believe, as Chief Justice Roberts claims to, that everyone should not be forced to accept a particular, controversial conception of marriage should embrace rather than oppose Obergefell.

Of course, it does not follow that people should believe that the marriage question ought to be resolved privately rather than publicly. The choice between public and private resolution rests on the answers to controversial questions about issues like the appropriate role for constitutional text, whether the Constitution establishes a presumption in favor of individual or political choice, the extent of 
externalities produced by individual decisions, the extent to which these decisions are truly "free," and whether paternalism is a legitimate basis for collective action. Although the Obergefell Court is not deciding for everyone how "marriage" should be conceived, it is implicitly resolving at least some of these issues.

Making the right choice between public and private is a problem, alright, but it is at this point that Chief Justice Roberts misconceives the solution. He and the other dissenters insist that the solution is to remit all questions to majority rule unless the Constitution leaves them to individuals. On this view, the Court should remain aloof from the battle between the contending forces. It should enforce only constitutional judgments, not its own. Unfortunately, though, this sort of neutrality is a logical impossibility at least if one accepts the starting premises of our constitutional tradition.

To understand why this is so, we need to examine the microstructure of the plaintiffs' argument in Obergefell. Although the majority focused primarily on the plaintiffs' due process argument, the point is easiest to see with regard to their equal protection claim. That claim can be reduced to a simple assertion: The government has left decisions forming heterosexual unions to individual, private action; it treats gay men and lesbians unequally when it forces them to accept a collective, public decision about their unions.

The claim is plausible, but only if gay marriages are relevantly the same as straight marriages. The equal protection clause requires that likes be treated alike, but when two things are not alike, it violates rather than vindicates equality to treat them in the same way. Are gay and straight marriages relevantly alike? All of the hard work must be done by defining the word "relevantly." Gay and straight marriages are both alike and unalike along an infinite number of dimensions. The key point is that it is impossible to decide which dimensions are relevant without making a contestable moral judgment about the institution of marriage. 
Justice Alito's dissent makes the point with startling clarity. He apparently concedes, at least arguendo, that on a "consent-based" conception of marriage, gay men and lesbians have a legitimate claim to marriage, but, he insists, their claim is much less powerful on a "conjugal" conception of marriage. ${ }^{52}$ Suppose we put aside questions about whether the "conjugal" conception really justifies our rules about heterosexual marriage and really rules out homosexual marriage. ${ }^{53}$ Whether or not he has the right categories, Alito is certainly right that we cannot resolve issues about whether heterosexual and homosexual marriage are the same without making a judgment about what marriage is for.

But what follows from this observation? It emphatically does not follow that heterosexual marriage is for the private sphere while homosexual marriage is for the public sphere. The equal protection clause requires that likes be treated alike, so a Court that reached this conclusion would have to believe that gay and straight marriage are not alike. It would have to embrace the "conjugal" conception (or some other conception that distinguished between the two forms of marriage) as the right one. But embracing that conception would violate the neutrality that the dissenters insist upon. ${ }^{54}$

In many cases, the Court resolves this problem by paying substantial deference to the political branches on questions of sameness and difference. With regard to "ordinary social and economic legislation," the Court sometimes asks only whether the legislature was "rational," although more exacting scrutiny is required for other sorts of classifications. ${ }^{55}$ The dissenters present no argument why

\footnotetext{
52 See id. at __ (Alito, J., dissenting).

53 The argument for these propositions must deal with the obvious facts that many people in heterosexual marriages do not raise children and many people in homosexual marriages do.

$54 \quad$ We might be closer to a neutral regime if we completely privatized marriage. One could imagine a regime where anyone could marry anyone else without state involvement of any kind. Even this radical reform could not escape state involvement, however. State and federal governments would still need to decide which marriages were eligible for the various benefits and obligations that attach to marital status.
}

55 See, e.g., Massachusetts Bd. of Retirement v. Murgia, 427 U.S. 307, 314 (1976) (“legislative classifications are valid unless they bear no rational relationship to the State's obectives"); Dandridge v. Williams, 397 U.S. 471 , 
mere rationality should be sufficient in this case, and there is strong reason to believe that the choice of level of scrutiny is, itself, the result of contestable moral and political views. For example, Chief Justice Roberts thinks that affirmative action measures should be viewed with suspicion because "divvying us up by race" is a "sordid business" 56 that is "pernicious," ${ }^{57}$ and "odious to a free people." ${ }^{58}$ Justice Thomas has reached a similar conclusion because of his belief that African Americans can succeed without it. ${ }^{59}$ If these justices thought that discrimination against gay men and lesbians were similarly problematic, they would presumably utilize the same level of scrutiny.

Moreover, even when scrutiny is minimal, the justices do not altogether forego enforcement. It follows that even if the dissenters were to apply rational basis review, they would have to decide whether a particular conception of marriage was "rational." For example, the dissenters would almost certainly invalidate a statute that prevented couples unable to conceive a child or from different ethnic or economic groups from marrying. But that holding, like the holding in Obergefell, requires a moral judgment about the appropriate nature of marriage.

The Court might avoid moral judgment if it completely forewent enforcement. There is much to be said for this approach, and some who have said it. It seems improbable to say the least, but perhaps Chief Justice Roberts and his dissenting colleagues wish to join the small but growing chorus of rebels opposing the orthodoxy of constitutional obligation and Supreme Court supremacy. ${ }^{60}$ What seems more likely is that the dissenters' distaste for gay marriage leads them to make an exception to

\footnotetext{
485 (1970) ("state legislation "does not violate the Equal Protection Clause merely because the classifications [it makes] are imperfect.")

$56 \quad$ League of United Latin American Citizens v. Perry, 548 U.S. 399, 511 (2008) (Roberts, C, J., concurring in part, concurring in the judgment in part, and dissenting in part).

57 Parents Involved in Cmty. Sch. v. Seattle Sch. Dist. No. 1, 551 U.S. 701, 720 (2007) (Roberts, C.J.).

$58 \quad$ Id. at 745-46 (Roberts, C. J.).

59 See, Grutter v. Bollinger, 539 U.S. 306, 349 (2003) (Thomas, J., concurring in part and dissenting in part) (I believe blacks can achieve in every avenue of American life without the meddling of university administrators.") 60 See, e.g., Jeremy Waldron, The Core Case against Judicial Review, 115 YALE L. J. 1346 (2006); MARK V. TUSHNET, TAKING THE CONSTITUTION AWAY FROM THE COURTS (1999); LOUIS MICHAEL SEIDMAN, ON CONSTITUTIONAL DISOBEDIENCE (2012).
} 
the conventional rules of American constitutionalism for this case. Obviously, such an exception is also inconsistent with the dissenters' insistence on neutrality in our culture wars.

There is still another reason why judicial deference does not solve the underlying problem. Deference to the political branches should not be confused with the view that constitutional commands should simply be ignored. When the Court defers, it assumes that constitutional commands will be enforced legislative and executive officials. For reasons explained above, these officials would then have to incorporate controversial moral judgments into the Constitution. That fact shines a very different light on the dissenters' complaint about taking the same-sex marriage question away from the people. A conscientious legislator who is serious about enforcing the Constitution should not obey the commands of his constituents. Instead, he should obey the commands of the Constitution - including the controversial moral judgment about marriage that give content to those commands. Either way, Justice Alito's choice between conceptions of marriage would not be open to democratic contestation.

Of course, few believe that political officials actually take seriously their supposed obligation to obey the Constitution, at least in this context. If that is the outcome that the dissenters favor, then we should not take seriously their rhetoric about adherence to constitutional limits. In that event, the Constitution would, indeed, have "nothing to do with it."

\section{II. “Celebrate the Constitution"?}

It will not do, then, to claim that the Constitution has "nothing to do" with Obergefell. It has everything to do with it. Neither does it follow, though, that we should celebrate either the Constitution or Obergefell's embrace of our constitutional tradition.

Obergefell, like scores of other constitutional decisions, rests on a syllogism the structure of which is as fallacious as it is familiar: 
Major Premise: We have a duty to adhere to the commands of the Constitution.

Minor Premise: The Constitution commands X.

Conclusion: At least until the Constitution is changed, we have a duty to do X.

The truth of the major premise rests on the belief that properly understood, the Constitution provides a just basis for resolving disputes among people who would otherwise disagree. The truth of the minor premise rests on the belief that we can discern the meaning of the Constitution without presupposing an extra-constitutional resolution of that disagreement. Because both of these beliefs are false, the conclusion does not follow.

Consider first the major premise. People often claim that we have a duty to obey the Constitution because it produces good results - for example, a right to gay marriage. Unfortunately, this claim involves a conceptual mistake. A person who would do something anyway even if not commanded to do it is not obeying the command. No one would say that a Jew who keeps Kosher is obeying the Koran. The test for obedience comes when the command requires us to do something that we would not otherwise do.

It follows that people who say that we should obey the Constitution because of the good outcomes it produces are actually insisting that others obey, not that they themselves should obey. Their own obedience is conditional on the command producing results that they favor, yet they want others to obey even though it produces the wrong result from their point of view. It is, an uphill climb to say the least to explain why others should have an obligation from which the person insisting on the obligation exempts herself.

To test the first premise, then, we have to imagine a constitutional command is clear and that it commands something that we would otherwise strongly oppose. For most readers of this article, the test requires turning the Court's holding in Obergefell inside out. Imagine, then, that provisions in the Constitution, written over two hundred years ago, unambiguously commanded that gay people should 
not be allowed to marry. Imagine as well (actually imagination is unnecessary here) that the mechanisms for changing the constitutional command are so cumbersome as to be virtually useless. Does this command, standing by itself, provide a just basis for resolution of the dispute about gay marriage? Does it provide a good reason why people who favor gay marriage should change their minds and now oppose efforts (short of constitutional amendment) to implement it?

I have written a book and several articles about why I think the answers to these questions are "no." ${ }^{61}$ Nothing would be gained by repeating all those arguments here. Suffice it to say that it is far from self-evident that a document written by others containing a noxious command that, as a practical matter, cannot be changed should definitively resolve a dispute about whether the command should be obeyed.

Nor does it solve the problem to argue that even if this command is noxious, the Constitution does more good than evil. That argument still rests on a claim that, overall and all things considered, the Constitution commands what the person making the argument thinks of as the right result and would favor even if there were not a constitution. Put differently, the command is doing no work for the person making the argument, even though that person insists that it should do work for others.

Matters are made much worse because the belief underlying the second premise is also false. If the command is, in fact, contained in the Constitution, then the many people who are unconvinced by my arguments will think that we must obey it. But for reasons that I have already set out, ${ }^{62}$ we cannot determine whether the Constitution contains the command without judging for ourselves its correctness. One must hold some controversial conception of marriage in order to decide whether gay

61 See id; Louis Michael Seidman, The Secret History of American Constitutional Skepticism: A Recovery and Preliminary Evaluation, 17 U. PA. J. CON. LAW. 1 (2014); Louis Michael Seidman, Why Jeremy Waldron Agrees with Me, 127 Harv. L. Rev. F. 159 (2014); Louis Michael Seidman, Constitutional and Political Obligation, 93 B.U. L. REV. 1257 (2013) 
and straight marriage are relevantly similar. More broadly, it is simply not possible to give determinate content to commands like "don't deny equal protection" or "provide due process" without first resolving the very moral and political controversy that the Constitution is supposed to settle.

Because I have done so elsewhere, I won't bore readers with elaborate argumentation supporting this proposition either. Instead, in what follows, I explore some of the pernicious consequences that flow from this failed logic.

The first and, perhaps most serious consequence is that disputants forced into a procrustean mold of constitutional argument end up alienated from their own, deeply held positions. Consider in this regard the plight of opponents of gay marriage. At least in its most defensible form, their opposition is rooted in a simple argument: There is no right to gay marriage because it is immoral, inconsistent with human flourishing, degrading, and unnatural. ${ }^{63}$

To be clear, I have no sympathy for this argument. I think that it is question-begging, unconvincing, and, indeed, barely comprehensible. Still, it is a view honestly held by millions of Americans, and it is at the center of the debate about same-sex marriage.

What happens to this argument when it gets fed into our constitutional law machine? Recall that the major premise rests on the position that constitutional law provides a just basis for resolving disputes among people who would otherwise disagree. Perhaps that position could be sustained if it were shown that the Constitution was somehow neutral as between rival views. As we have already seen, though, there is no way to supply the content of the " $X$ " in the minor premise without taking a position on the very issue in dispute. To make the syllogism plausible, then, a court must demonstrate that it has come to $X$ through the use of presuppositions that are very widely shared.

The chief such presupposition concerns means-ends rationality. Because we disagree about many ends and because this disagreement threatens the unanimity that the major premise requires, we

63 See. e.g., Robert P. George \& Gerard V. Bradley, Marriage and the Liberal Imagination, 84 GEO. L. J. 301 (1995); John M. Finnis, Law, Morality, and "Sexual Orientation," 69 NOTRE DAME L REV. 1049 (1994). 
are forced into assuming ends that are uncontroversial and then arguing about whether the chosen means really advance those ends.

Judge Posner's widely admired opinion for the Seventh Circuit Court of Appeals striking down gay marriage bans in Wisconsin and Indiana demonstrates what happens to constitutional argument when this process is operationalized. ${ }^{64}$ Judge Posner notes that neither Wisconsin nor Indiana "make[s] a moral argument against permitting same-sex marriage." ${ }^{65}$ Instead, the states made consequentialist arguments, like the assertion that "the only reason government encourages marriage is to induce heterosexuals to marry so that there will be fewer 'accidental births,' which when they occur outside of marriage often lead to abandonment of the child to the mother (unaided by the father) or to foster care." ${ }^{\prime 66}$ Same-sex couples, in contrast "don't need marriage because [they] can't produce children, intended or unintended. "

With characteristic verve and acuity, Judge Posner proceeds to demolish this argument, demonstrating that it "is so full of holes that it cannot be taken seriously." ${ }^{68}$ And the argument is indeed silly. But whose fault is that? The states can hardly be blamed for not making the argument that gay relationships are immoral. By the time the Seventh Circuit case was argued, the Supreme Court had already taken that argument off the table. ${ }^{69}$ Having been deprived of the argument that motivated

See Baskin v. Bogan, 766 F. 3d 648 (2014).

Id. at 668 .

Id. at 664 .

Id. at 656 .

Id.

See Lawrence v. Texas, 539 U.S. 558, 569 (2003):

The condemnation [of homosexuality] has been shaped by religious beliefs, conceptions of right and acceptable behavior, and respect for the traditional family. For many persons these are not trivial concerns but profound and deep convictions accepted as ethical and moral principles to which they aspire and which thus determine the course of their lives. These considerations do not answer the question before us, however. The issue is whether the majority may use the power of the State to enforce these views on the whole society through operation of the criminal law. Our obligation is to define the liberty of all, not to mandate our own moral code. 
them, gay marriage opponents were left with no alternative but to make substitute arguments that, not surprisingly, ill-fit the position they were defending.

There is little mystery about why the Supreme Court disallowed the morality argument. It is, at best, controversial, and the prospect of resolving the controversy by resort to presuppositions that are widely shared is nil. And so, in order to preserve the first premise, courts ignore the argument and replace it with another argument about rational means to an uncontroversial end. Judge Posner then gets to make fun of the litigants for defending a means that any intelligent person would see is completely disconnected from the posited end. Often, this display is coupled with dark hints that this disconnect demonstrates lack of good faith and candor. Perhaps the litigants are merely stupid, but if we assume that they are intelligent, then their seeming irrationality must be caused by the effort to advance some secret end that they are not revealing.

Playing this game is no doubt satisfying to the winners and demonstrates their intellectual and moral superiority, at least to their own satisfaction. The problem, though, is that the game is rigged. One can always win an argument if one starts by disqualifying the principal position of one's opponent. ${ }^{70}$ It will not do to claim that moral arguments in general cannot justify laws. All laws have moral substrates. The Court remains blind to this fact in the same way that many white people think that they have no race. Requirements imposed by means/ends rationality, the harm principle, and welfare maximization themselves rest on moral presuppositions that the Court treats as neutral and "just there" only because they are familiar to the justices. If one starts instead with a different set of premises, the

70 The phenomenon extends beyond the gay marriage debate and has become an important feature of constitutional law. For example, advocates of affirmative action are forced to make sometimes unconvincing arguments about diversity because the Supreme Court has taken the aim of ending racial subjugation off the table. Similarly, advocates of campaign finance regulation must make sometimes unconvincing arguments about quidpro-quo corruption because the Supreme Court has taken the aim of equalizing political power without regard to wealth off the table. For my argument that substitution is a defining characteristic of constitutional law, see Louis Michael Seidman Substitute Arguments in Constitutional Law (forthcoming). 
wrongness of gay relations might be "just there," and then the prohibition of gay marriage would be a completely rational means that uncontroversially advances the end of discouraging immoral behavior.

All this is sufficiently obvious that there is a risk that the sham will be seen for what it is. For this reason, the basic moves of the game need to be supplemented with other rhetorical tropes. At this point, a second pernicious consequence of constitutional argument emerges. In order to make the argument plausible, the losing position must be painted as not only wrong, but also outside the bounds of reasonable discourse. The winning position, in turn, must be painted as not only right but also uncontroversial, and to make it uncontroversial, it must be distinguished from other positions that might raise problems.

That effort, in turn, gives the new recognition of constitutionally protected groups a curious, double-edged quality. Even as the Supreme Court extends the bounds of empathy and connection to the previously excluded, it frequently does so against the backdrop of other disfavored groups that are left all the more isolated.

There is a history to this. When the first Justice Harlan wrote his celebrated dissent in Plessy v. Ferguson ${ }^{71}$ deploring the forced segregation of African Americans, he felt called upon to distinguish them from the "[Chinese] race so different from our own that we do not permit those belonging to it to become citizens of the United States."72 Generations later, when Harlan's grandson wrote to defend the right of married couples to use contraceptives, he wrote that "I would not suggest that ... homosexuality ... [is] immune from criminal enquiry, however privately practiced." 73 Years after that, Justice Kennedy wrote an opinion striking down a provision that erected special barriers that prevented gay men and lesbians from securing passage of antidiscrimination laws that benefited them. ${ }^{74}$ Coming

\footnotetext{
$71 \quad 163$ U.S. 539 (1896).

72 Id. at 561 (Harlan, J., dissenting).

73 See Poe v. Ullman, 367 U.S. 497, 552-53 (Harlan, J., dissenting) incorporated by reference Griswold v. Connecticut, 381 U.S. 479, 500 (1965) (Harlan, J., concurring).

$74 \quad$ See Romer v. Evans, 517 U.S. 620 (1996).
} 
full circle from the first Justice Harlan's dissent, Justice Kennedy subsequently made clear that this decision had nothing to do with provisions that similarly obstructed passage of affirmative action laws benefiting African Americans. ${ }^{75}$

Who are the disfavored groups victimized by Obergefell? The most obvious candidates are religious and cultural conservatives. In fairness to the majority, it goes out of its way to express respect for these groups. There is, moreover, a difference between merely losing and being effectively excluded from the political community. Still, a necessary consequence of resting the decision on the duty to obey constitutional commands is that people on the other side are painted as not just wrong but as opposing the fundamental commitments under which our society is organized. Yes, "[m]any who deem same-sex marriage to be wrong reach that conclusion based on decent and honorable religious or philosophical premises" ${ }^{\prime 76}$ but that does not change the fact that their position is not just wrong, but denies "the liberty promised by the Fourteenth Amendment."77

Perhaps more disturbing is the majority's marginalization of people - gay and straight - who cannot or choose not to marry. The belittling of the millions of unfortunate Americans who fall into this category begins in the first paragraph of the Court's analysis and does not end until the last paragraph. At the beginning of the opinion, we learn that "marriage is essential to our most profound hopes and aspirations," 78 apparently leaving the unmarried hopeless and without aspirations (at least of the profound variety). At the end, we are told that gay people must be allowed to marry so as "not to be condemned to live in loneliness" 19 as if unmarried people necessarily lack human connection and companionship.

75 Compare id. with Schuette v. Coalition to Defend Affirmative Action, Integration \& Immigrant Rights \& Fight for Equality by Any Means Neessary,134 S. Ct. 1623 (2014) (Kennedy, J.)

76 Obergefell v. Hodges, 135 S. Ct. 2584, _ (2015).

77 Id.

$78 \quad$ Id. at

79 Id. at 
In between, the Court informs us that marriage "fulfils yearnings for security, safe haven, and connection that expresses our common humanity." 80 It allows persons to find "expression, intimacy, and spirituality," 81 "supports a two-person union unlike any other in its importance to the committed individuals," 82 and "responds to the universal fear that a lonely person might call out only to find no one there." ${ }^{83}$ Without the right to marry, gay men and lesbians are "outcast." ${ }^{84}$ Children of unmarried people suffer "stigma." 85 Worse yet, there is at least an implication that unmarried people are not quite full citizens. This is so because "marriage is a keystone to our social order" 86 and "remains a building block of our national community." ${ }^{87}$

All this rhetoric takes no account of the fact that for many victims of spousal abuse, marriage is a cage that denies them "security, safe haven, and connection." Nor does it recognize that many unmarried people are quite capable of finding fulfilment, happiness, and civic engagement. Nor does the Court's blithe assumption that $[\mathrm{m}]$ arriage ... affords the permanency and stability important to children's best interests" ${ }^{\prime 8}$ take into account the fact that something like half of all marriages end in divorce. ${ }^{89}$

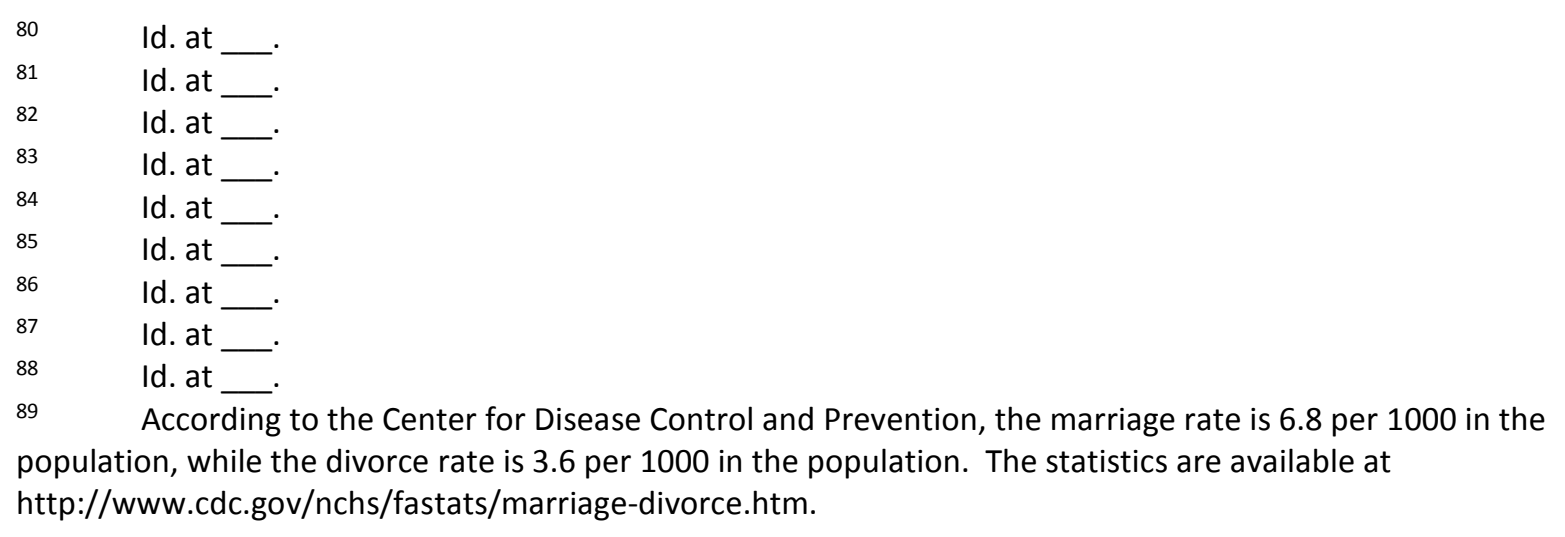


The valorization of marriage and attack on the unmarried is also deeply reactionary. It comes at a moment when, as just noted, a huge percentage of marriages end in divorce - often acrimonious and wrenching -- and when fewer and fewer Americans are choosing marriage in the first place..$^{90}$

This lack of empathy and understanding for a choice that many make and a necessity that many face is especially incongruous in an opinion that purports to argue for inclusion and understanding. The majority is on firm ground when it points to the human misery caused by insisting on a limited number of social scripts to which people must conform whether or not it suits their circumstances. It is therefore especially unfortunate that the very opinion that lauds the virtues of inclusion and respect also thoughtlessly attacks a central feature in the lives of so many.

Ironically, the majority's characterization of the unmarried also oversimplifies the experience of the gay Americans it purports to defend. The opinion effectively reads out of the gay rights movement those who advanced a radical critique of mainstream sexual mores. Moreover, from reading the opinion, one might suppose that before rescued by a beneficent Court, gay men and lesbians were "outcast $[\mathrm{s}]$ "91 condemned to a lonely existence without hope or aspiration. Of course, no one should deny the history of oppression, violence, and exclusion suffered by the gay community. But gay people, like other oppressed minorities, managed to develop a sustaining culture in the face of that oppression. Part of what made the culture sustaining was that it stood in opposition to the majority culture. Contrary to the implication of the majority opinion, all gay people were not isolated and miserable. They formed communities, had fun, lived productive lives, and gained sustenance from their association

$90 \quad$ Center for Disease Control and Prevention statistics show that between 2000 and 2012, the annual marriage rate declined from 8.2 per one thousand in population to 6.8 per one thousand in population. The statistics are available at http://www.cdc.gov/nchs/nvss/marriage_divorce_tables.htm.

91 Obergefell v. Hodges, 135 S. Ct. 2584, (2015). 
with each other. ${ }^{92}$ The majority's condescending pity toward their oppositional culture is inconsistent with the very inclusive pluralism that it purports to embrace.

Constitutional argument distorts the experience of the gay community in yet another way. As I have argued above, the constitutional dispute about gay marriage revolves around whether the issue should be resolved publicly or privately. Because the Court's opinion defended private choice, its rhetoric necessarily celebrated the virtue of unfettered individualism and autonomy. On the Court's view, "the right to personal choice regarding marriage is inherent in the concept of individual autonomy." 93

Few today would deny that individual choice is an important aspect of marriage. It should be obvious as well that liberty and autonomy are an important part of what gay liberation is about. But the fight for gay liberation also involved instilling the kind of group solidarity necessary to overcome the huge collective action problem posed by the closet. ${ }^{94}$

The story is a familiar one. So long as gay people saw themselves as atomized individuals, there was little hope for effective political action. If left to the kind of individual choice that the Obergefell Court celebrates, it made little sense to many gay people to take the huge risks associated with coming out. With exit a plausible option, voice was foolhardy.

The solution to this dilemma was not individual, unfettered choice, but collective action. The most extreme strategy for promoting collective empowerment was the practice of "outing." Defenders of the practice argued that closeted gay people were not simply making an individual choice. Their failure to give voice inflicted externalities on others by reducing the political power of the gay

92 For a detailed revisionist history emphasizing the vibrancy and visibility of the gay community before World War II, see GEORGE CHAUNCEY, GAY NEW YORK: GENDER, URBAN CULTUREK, , AND THE MAKING OF THE GAY MALE WORLD, 1890-1940 (1994).

$93 \quad$ Obergefell v. Hodges, 135 S. Ct. 2584, ___ (2015).

94 For one account, see MICHAEL J. KLARMAN, FROM THE CLOSET TO THE ALTER: COURTS, BACKLASH AND THE STRUGGLE FOR SAME-SEX MARRIAGE (2013). 
community. For the good of the collective, their individual choice had to be countermanded by revealing their sexual identity against their will. $^{95}$

For obvious reasons, "outing" is problematic, but there were other much less troubling strategies that eventually succeeded in creating the kind of collective consciousness that made gay liberation a real possibility. Remarkably courageous leaders provided examples and role models. Iconic events like Stonewall provided causes to rally around. Gay pride parades and demonstrations showed that coming out could be empowering and joyful. These were not decisions made by individuals concerning how to lead their private lives. They were public manifestations of solidarity.

The public character of gay liberation involves not just means but also ultimate ends. Although Obergefell makes passing reference to the equal protection clause, ${ }^{96}$ the Court places its primary emphasis on due process rights. The distinction is important because the due process clause is the natural home for individualist claims. As the dissenting opinions point out, the dominant strain of our constitutional tradition emphasizes the negative right of the individual to be shielded from the collective, not the positive right of groups to collective protection. ${ }^{97}$

Equality claims, in contrast, provide the one constitutional mechanism through which the government can be forced to extend positive protection to groups. If one group is denied things that others are granted, an equal protection argument can force the state into a choice of denying the benefit to everyone or granting it to the deprived group. Often, the government will choose to extend the benefit. And although the Court has recognized the conceptual possibility of an equal protection

95 For a discussion, see Kenji Yoshino, Covering, 111 YALE L. J. 769, 821 (2002).

$96 \quad$ Obergefell v. Hodges, 135 S. Ct. 2584, __ (2015).

97 See Obergefell v. Hodges, 135 S. Ct. 2584, dissenting). (2015) (Thomas, J., dissenting); id at (Roberts, C.J., 
"class of one," 98 equality claims prototypically involve groups of people who are treated differently from each other.

Occasionally, the Supreme Court has utilized the equal protection clause to mandate collective, positive rights, but the dissenting justices are correct when they insist that this is not the dominant strain of American constitutionalism. The majority therefore needed to shield itself from the claim that it was embracing this strain. It did so by recasting the problem for gay Americans as the frustration of an individual choice to marry that was part of the "liberty" that the due process clause protects.

That is part of the problem faced by gay Americans, but it is nothing like the whole problem. As Chief Justice Roberts points out, individual people face all sorts of restrictions on marital choice, including, most prominently, the restriction on polygamy. ${ }^{99}$ The majority provides no answer to the Chief Justice's complaint that its opinion opens the door to constitutional protection for polygamists. To provide an answer, the majority would have had to acknowledge the public, group nature of the claim to gay marriage.

That claim is not premised solely on the frustration of individual choice (a characteristic it shares with polygamy), but on the fact that restrictions on gay marriage are part of a system of laws, practices, customs, and beliefs that subjugate gay men and lesbians as a group in a way that individuals who want more than one spouse are not subjugated. People who would like to be married to more than one spouse are not routinely beaten up, ridiculed, despised, and excluded from employment or public accommodations. ${ }^{100}$ Nor are they part of a group formed by genetic or at least very deeply rooted characteristics that go to the core of their identity and that are not subject to change.

98 See Village of Willowbrook v. Olech, 528 U.S. 562 (2000) (recognizing a "class of one). But cf. Engqist v. Oregon Dept. of Agriculture, 553 U.S. 291 (2008) (refusing to recognize "class of one" in cases where government is acting as employer).

$99 \quad$ Obergefell v. Hodges, 135 S. Ct. 2584, ___ (2015) (Roberts, C.J., dissenting).

100 The difference is significant now, but was less so when polygamy was associated with the Church of the Latter Day Saints, which was a group and suffered from oppression. Today, people who wish to marry more than one spouse find their choice frustrated, but they do not suffer widespread discrimination, violence, subjugation, or 
Moreover, the solution to the problem involves much more than just recognizing the right of gay men and lesbians to be "let alone." As Chief Justice Roberts rightly points out, bans on gay marriage create no crime and impose no punishment. Same-sex couples remain free to live together, to engage in intimate conduct, to raise their families as they see fit. ... [T] he laws in no way interfere with the "right to be let alone."101

After years of official oppression, a commitment by government to leave gay men and lesbians in peace is no doubt an advance. But it is far from all that is required. Much of the most serious oppression of gay Americans stems from private violence, hatred, and discrimination. To ward that off, positive government intervention to control private sphere is required. Most obviously, the protection consists of punishment of private violence, but there is more to it than that. Just as the dissent complained, gay marriage is important because it provides affirmative government endorsement of relationships that were once scorned. It is a symbolic part of the project of tearing down the closet that hid individual gay Americans from view. It turns them into visible, public citizens worthy of public respect.

It is similarly fallacious to suppose that this transformation produces no externalities. Contrary to the claims its defenders must make to fit within our constitutional tradition, same-sex marriage decisions are not solely self-regarding. Of course, the assertion that straight people will no longer marry because gay people do is ludicrous, but the assertion that the end of the closet will have an impact on American culture is not. Does anyone suppose that one can shield oneself from the profound effects of television and computers on everyday life by not purchasing these products? These innovations transformed our entire society, whether one personally used them or not. So, too, the end of the closet affects all of us, gay or straight, in sometimes subtle but pervasive ways.

hatred so long as they do not violate the laws against their marital preferences. One could imagine that at some point in the future, polygamists would regain a group identity and solidarity that would make them more similar to gay men and lesbians.

101 Obergefell v. Hodges, 135 S. Ct. 2584, _ (2015) (Roberts, C.J., dissenting). 
These are changes that can only be defended on the merits. The defense ultimately rests on the assertion that gay intimacy is a good and that suppression of it is an evil. Conventional constitutional argument lacks the resources to defend that assertion. There is not some neutral principle contained in the text of the Constitution or in a tradition that everyone is bound to accept that establishes its truth. Instead, the truth comes from lived experience, from a sense of solidarity and empathy, and from the pull of fundamental decency - or at least so it seems to me. It will not seem that way to religious and cultural conservatives, who think that homosexuality offends the natural order. Anyone who supposes that constitutional law can bridge that gap misunderstands its nature and depth.

Truly respecting the losers in Obergefell entails recognizing that fact. We should not trivialize their objections by pretending that they are relying on an argument that we have forced them into making or by insisting that their actual argument is inconsistent with a neutral and objective reading of our founding document. The governors, attorney generals, and justices of the peace who resist Obergefell should not be told that they have a constitutional duty to comply regardless of the moral rightness of the decision. From their perspective, they have a duty to resist. What they should be told instead is that their perspective is wrong - at least from our perspective.

Of course, telling them this will not resolve the dispute, but neither should constitutional law. It is just a fact that our society is divided about questions that matter. If the divide is to be bridged at all, it will have to be by a sense of cooperation and solidarity that comes from engaging in a joint enterprise. Vague words in an ancient text should not be allowed to do the trick.

\section{What to do?}

No doubt, the governors, attorney generals, and justices of the peace will come around, albeit after some symbolic, short-lived unpleasantness. We are unlikely to see the kind of massive resistance that followed Brown or even the sustained political opposition that followed Roe. There are a variety of reasons for this acquiescence. Gay marriage does not disrupt an entrenched system in the way that 
Brown did. The Court did not embrace and, indeed, effectively isolated the strands of the gay rights movement that might have posed a challenge to the reigning ideology. Moreover, the decision does not provide the numerous possibilities for evasion that existed after both Brown and Roe. And whereas the country was narrowly divided about both desegregation and abortion, there is a large and growing majority favoring gay marriage. ${ }^{102}$

It must be conceded, though, that acquiescence also stems in part from a widespread belief that when the Supreme Court speaks in constitutional tones, its dictates appropriately settle the issue, at least until the decision is overruled. People who challenge the Court are said to be violating the rule of law and the Constitution itself, and many people think that that is a very bad thing.

The confluence of these forces has produced an undeniable, if partial and tainted victory. The day after Obergefell, there was indeed cause for dancing in the streets. People who had suffered years of exclusion and oppression finally achieved some recognition of their basic humanity. If Chief Justice Roberts cannot bring himself to begrudge them their celebration, then neither can I.

Still, when the dancing stops, we are left with some disturbing questions. Constitutionalism helped produce a victory in this case, but it did so through mechanisms we should be ashamed of. Should we embrace constitutionalism and use its tools so as to preserve this victory and, perhaps, win others as well? Put differently, if you or I were a justice on the Supreme Court, should we sign Justice Kennedy's opinion? What if our vote was necessary to secure a majority?

It is worth emphasizing again that the test for authentic constitutional obedience comes only when it produces bad outcomes. In this case, the outcome was good, and the substantive "rightness" of Obergefell means that it cannot pose such a test, at least for those of us who believe that the outcome is substantively right. The real question, then, is whether the substantive rightness of this

102 See note $\mathrm{x}$, supra. 
particular outcome provides sufficient reason to associate ourselves with a discourse that is corrupt and obfuscatory.

That question is most difficult if one assumes that not just in this case, but over the range of cases, American constitutionalism produces or is likely to produce substantively good outcomes. There is a huge literature that I cannot do justice to here arguing that Court has only rarely stood for progressive social change and that, when it has attempted to do so, it has only rarely been successful. Much more frequently, the justices have stood with the forces of reaction and privilege or backed down when confronted with opposition to progressive change. ${ }^{103}$

The gay rights story provides a partial corrective to this general narrative. The Court's decisions hastened the advent of gay marriage, and, for reasons I have just discussed, it seems quite likely that the reforms will stick. Still, even in this instance, judicial intervention was facilitated by exogenous social change that had little to do with constitutional litigation. By the time the Court finally got around to recognizing a right to gay marriage, the political and cultural isolation of gay men and lesbians was already quickly disappearing. It is probable that gay marriage would have been recognized almost everywhere within a decade or two even if the justices had not intervened. The Court's very gradual advance toward mandating gay marriage, extending over several decades, amounted to an admission that it felt unable to affect change until the point when its efforts were largely unnecessary.

Moreover, as argued above, the victory for gay marriage came at the cost of distorting the argument for and against it and further isolating others who do not live within the territory of empathy that the Supreme Court has bounded. And against the ambiguous and partial advance that protection for gay marriage represents, we must weigh all the unjust settlements that the Court and our sense of

103 For an introduction, see Michael J. Klarman, Rethinking the Civil Rights and Civil Liberties Revolutions, 82 VA. L. REV. 1 (1996); GERALD N. ROSENBERG, THE HOLLOW HOPE: CAN COURS BRING ABOUT SOCIAL CHANGE? (1991). But cf. Justin Driver, Constitutional Outliers, 81 U. CHI. L. REV. 929 (2014) (rejecting view that Court only invalidates measures that are already deemed antiquated). 
constitutional obligation have forced upon us. For every Obergefell v. Hodges, we have many Bush v. Gores, Hellers, and Citizens Uniteds. Is the game really worth the candle?

I think that it probably is not, but that doesn't quite settle the matter. What if it is possible to use the tools of constitutionalism in bad faith to produce good results in this case while disowning them when they produce bad results in other cases? Should you or I then sign Justice Kennedy's opinion ?

There is a risk, of course, that we will be caught at this dishonest game or outsmarted by our opponents. Even if we are not, there are obvious problems of political morality at stake. If skillfully deployed, the tactic might marginally help produce a more substantively just society, but it does so only by removing from debate issues that ought to be contestable. There is no good reason grounded in political justice why people who disagree about, say, campaign finance, gun control, or gay marriage should be bound to put aside their principles and accept a particular judgment just because the Supreme Court thinks that the Constitution requires it. In place of these good reasons, constitutional law provides dishonesty, mystification, debate that has little relationship to what people do or should care about, and the false closure of authoritarian pronouncement. These characteristics of constitutionalism cannot be reconciled with the ideals of a mature, deliberative democracy. They do not accord our political opponents the dignity that they deserve.

If one would nonetheless sign Justice Kennedy's opinion, it must be because substantive justice trumps principles of political justice. It must be because those who are on the "right" side can appropriately insist on obedience for others that they would not accept for themselves. Is substantive justice the kind of trump that justifies this hypocrisy?

I am far from certain, but I'm inclined to think that it is. Put differently, if I somehow found myself on the Supreme Court, yes, I would be tempted to join Justice Kennedy's dreadful opinion. On one side of the ledger, there is the real and daily human suffering resulting from the status quo. On the other side, it is not as if my abstaining from our constitutional practice means that others will as well. If 
the practice is going to continue anyway, why not claim the benefits of the just results it occasionally produces?

I must concede, though that this affirmative answer leads to some disquieting conclusions. It means resorting to deception and manipulation to achieve our ends and giving up on the prospect of resolving disputes by means of authentic dialogue with a common vocabulary.

I am not at peace with that outcome. If we are to avoid it, the only alternative is to embrace the hard and urgent work of imagining a different, less authoritarian, distorting, and exclusionary discourse that can justly bind us together. 